\title{
THE ISSUES OF HEALTHCARE-ASSOCIATED INFECTIONS - THE ECONOMIC AND SOCIAL PERSPECTIVE
}

\author{
KLAUDIA TWARDOWSKA, MACIEJ JEWCZAK
}

\begin{abstract}
A B STRACT
The aim of the paper was to diagnose and analyse the rates of infections in Polish voivodships, and possible consequences from both economic and social perspectives of the changes in the levels of cases reported. For the analyses, data banks of Central Statistical Office in Warsaw were used, in particular, information on the incidence of infectious diseases and poisonings. The rates of changes and spatial concentration of the phenomena were investigated in the period between 2005 and 2015 . For estimates of regional trends, the Shift-Share Analysis was adopted, and the pattern of spatial distribution was defined on the basis of location quotients. Extreme values of location quotients were observed in Warmińsko-Mazurskie for shigellosis, in Lubuskie for trichinellosis, and for AIDS in Dolnośląskie. Location quotient values allowed identifying regions with a higher spatial concentration of infectious diseases incidences, which in turn could indicate areas and cases where preventive actions should be improved or modified. The Shift-Share Analysis resulted in pointing out regions that recorded a positive change in infection rates. The obtained results also demonstrated that in some cases, the impact of structural changes influences the net rates of infections more than the local components. The obtained results directly indicated objects (regions) where attention should be paid to prevention. Especially, the results of spatial distribution and concentration allowed a reliable analysis of the state of population incidence rates, as well as answered questions concerning the origin of rates whether the change derived from structural, local or overall tendencies. Results could be adopted, for instance, in preventive strategies of local governments. The estimates might be beneficial from the perspective of the healthcare system, due to easier predictive scenarios of future infection and possible centres with the increase in incidence.
\end{abstract}

KEY WORDS

healthcare-associated infections, regional comparisons, incidences of infectious, Shift-Share Analysis

DOI: 10.1515/emj-2017-0010 pages: $21-31$
Corresponding author:

Klaudia Twardowska

The Medical University of Lodz, Faculty of Health Sciences, Department of Health Care Policy, Field of Health Care Financing, Poland e-mail: klaudia.twardowska @umed.lodz.pl

Maciej Jewczak

The University of Lodz, Faculty of Economics and Sociology, Department

of Spatial Econometrics, Poland e-mail: jewczak@uni.lodz.pl

\section{INTRODUCTION}

The healthcare sector is one of the key components of any economy. During every parliament election, slogans can be heard about the necessary or planned changes that a political formation is prepared to introduce immediately. Patients regularly experience failed attempts to effectively meet their needs for medical services, not to mention the quality improve- ment. However, some of the changes, such as the introduction of the system for electronic verification of the eligibility to health benefits, are quite visible and have a positive connotation. With growing importance of IT technologies in the healthcare system, the large quantity of collected data creates further opportunities to differently define the use of 
quantitative methods that were previously reserved for economic evaluation.

The main objective of this paper is to analyse the spatial differentiation of healthcare-associated infection rates including their types and geographical diversification. The empirical research concentrated on the use of the methods of spatial statistics and econometrics: the method of shifts in both static and dynamic and spatial concentration. Due to the availability and comparability of data, the statistical analyses were performed for the years 2005-2015. The source of the data was the Central Statistical Office in Warsaw.

\section{LITERATURE REVIEW}

In 2002, four countries adopted legislation that required public health care organisations to disclose rates of healthcare-associated infections (HAI). Today, similar reports are being conducted in several other countries. Proponents of mandatory public reporting of HAI believe that disclosure of such information would improve the overall quality of health care by reducing HAI and give consumers the possibility to make more informed choices about their health (McKibben et al., 2005, pp. 217-226).

Infection control and programmes dedicated to infection control are well organised and characterised by their complexity. However, a lot of scientific papers refer to nosocomial infections and their spread. In addition, it might be noted that most of the articles devoted to infections present relationship between the implementation of recommendations in this field and their application (for instance, conducting microbiological tests or washing hands). Another frequently encountered analysis is a comparison between infection occurrences on the international scale or between Poland and Europe.

Under the section of HAI, the Centres for Disease Control and Prevention (CDC) provides definitions and characteristics of most bacteria, viruses and pathogenic fungi causing infections (CDC, 2016). However, this description does not include analyses of the infections in the Data and Statistics module, which would undoubtedly respond to the needs of the infection analysis in terms of the decomposition, change or tendencies. In the paper International study of the prevalence and outcomes of infection in intensive care units (Vincent et al., 2009, pp. 23232329), the authors focused on the global epidemiol- ogy of infections, mostly in several world's intensive care units (ICU).

In developing countries, healthcare-associated infections account for $10 \%$ of cases, and in the developed countries, they amount to $7 \%$ of patients under the medical and, mostly, hospital care. However, these infections must be controlled using antibacterial agents and immunity in combination with special antibiotic policy and infection control programmes (Cianciara, 2010).

An effective monitoring system could have an important impact on the international and national level. Efforts are demanded from all relevant actors within the control and prevention of infections (Khan, 2017). What's more, according to a study conducted under the supervision of the World Health Organization (WHO), in 2010, the average frequency of infections, including nosocomial infections represented within the countries of the Baltic Sea, amounted to $11.8 \%$ and in Europe $7.7 \%$ of total infections. In the Western Pacific Region, data on average indicated $9 \%$ of cases and $10 \%$ in Asia. However, due to disorganisation and the lack of convergence in the registration of infections, the two last-mentioned areas may be underestimated (Cianciara, 2010). This could easily indicate problems in determining the extent of hazards in this field, designing the appropriate strategies, and consequently mapping as well as introducing them by local governments. The comparison of the organisation and control of nosocomial infections in Poland and European countries can be found in the work Organisation and infection control in Polish hospitals. The results of PROHIBIT programme (Różańska, 2014, pp. 117-120).

The Authors believe that insufficient materials are available for analysis, such as specific quantitative analyses, or guidelines, or even full and comprehensive databases devoted to various issues related to infections, especially the time-cross-sectional distribution (for instance, for Polish NUTS-2 spatial units). Furthermore, the socio-economical frame for infections rates in voivodship makes this problem important from the perspective of the Authors as well as the society, which served as the basis for the Authors to undertake the research.

Despite the rapid development of knowledge and diagnostic techniques, the degree of exposure to infections has not decreased. The frequency of infection rates may indicate the safety and quality of the healthcare system. Hence, the emphasis is placed on the impact on residents' education, as well as the 
medical community to benefit from this knowledge (Denys, 2013, pp. 17-18).

Infections (in the broad sense) have become an important issue for the healthcare system in Poland. They can be divided using many different approaches that generally depend on the multidisciplinarity of the perspective. The Act of 5 December 2008 on Preventing and fighting infections and infectious diseases affecting humans, introduced an obligation to respond, register and supervise infected people as well as implement prevention and control of nosocomial infections (Ustawa z dnia 5 grudnia $2008 \mathrm{r}$. o zapobieganiu..., 2008; Dziewa, 2012, pp. 56-63).

In the literature, many definitions of an infection can be found. In each definition, common explanations are identified in accordance to which an infection is 'an unplanned infiltration of infection into the body', which can also be further elaborated by the explanation stating that it is a 'penetration into the body and multiplication of the pathogenic microorganisms that can cause disease. For a disease to be induced, the resistance of the body must be overcome. If symptoms of an infection are located in the vicinity of an infection, the condition could be described as a local infection. When the infection is accompanied by symptoms of an Inflammatory Response, this situation is called sepsis (Mała Encyklopedia PWN, 1995, p. 989). There are many classifications of infections, for instance, infections can be divided into:

- primary and secondary infections,

- local and generalised infection (sepsis),

- infection subclinical (asymptomatic), i.e. running infection without symptoms of a disease,

- infection abortifacient, i.e. having a mild and short course,

- superinfection - a re-infection with the same pathogen in the course of treatment or convalescence,

- reinfection - a re-infection with the same pathogen after recovery,

- food infection - an infection caused by pathogenic microorganisms present in food and water that entered through the digestive system,

- nosocomial infection - any infection associated with a hospital stay,

- endogenous infection - infection caused by the resident flora,

- mixed infection, caused by several different pathogens at the same time,

- droplet infection - an infection caused by pathogenic microorganisms that are found in inhaled air (Podręczny..., 1996, p. 781).
Furthermore, in the lexicon of medicine, a contagion is also defined as an infection. Depending on the virulence of pathogenic and the number of infectious agents, the reactivity of microorganisms and the place of penetration develops a contagious disease or a "silent infection", or results in a harmless infection which indicates a symbiotic coexistence with a physiological microbial flora, for example physiological microbial flora (Podręczny..., 1996, p. 781).

Infection can occur through several ways, such as air-pollen, ingestion (oral), direct and indirect contact, and by tearing of tissues. It needs to be highlighted that the risk of infection factors (nosocomial, for example) depends on the health condition of a patient, including:

- age, malnutrition, immunological deficiency,

- general disease, such as multi-organ injuries, diabetes, congenital and acquired immunodeficiency syndromes,

- comorbidity, such as chronic renal failure, the use of medications without indications, bedsores, long-term use of antibiotics, children staying at home, alcoholism, cirrhosis, organ transplantation (Profilaktyka..., 2016).

The research on the management of healthcare services, including the quality of research, must be carried out in accordance with the general principles of quality of health care. This means that various elements, such as technical, management, information, economic, administrative, medical and marketing fields, must operate together (Opolski et al., 2003, p. 29).

The quality of healthcare consists of many dimensions that can be assessed such as effectiveness (based on current scientific findings) and efficiency (use of economic analysis of different treatments), availability of services, safety, adaptation of services to existing needs of patients and ensuring equal access to services for all patients (Czerw et al., 2012, pp. 269-273).

\subsection{ECONOMIC AND SOCIAL COSTS OF INFEC- TIONS}

Infection surveillance is one of the priorities of healthcare in many countries around the world. This is an important element for the organisation of health care for patients and payers, health care management entities, doctors, economists and lawyers (Wójkowska-Mach, 2009, p. 87). A common phenomenon in healthcare is an excess of the demand for health services compared to the available health 


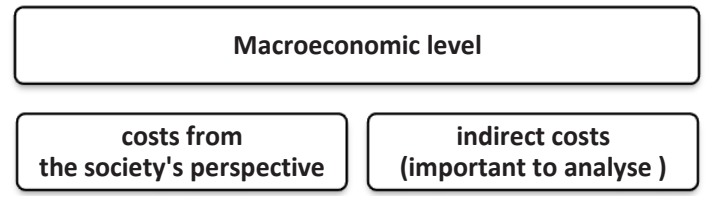

Fig. 1. Classification of costs levels

Source: authors' elaboration based on (Różańska, 2009b, p. 81)
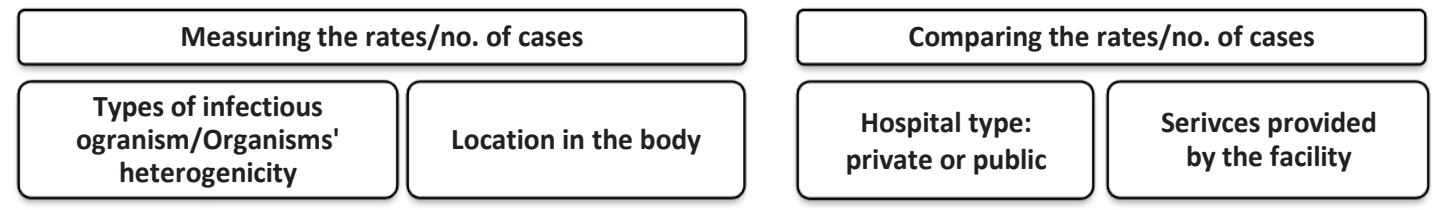

Fig. 2. Measurement and comparison of rates

Source: authors' elaboration based on (Khan et al., 2015, p. 512).

resources. The ideal situation occurs when health programmes, as well as a new medicine, is analysed not only for the effectiveness and efficiency of medical care but also in terms of economic viability. Depending on the needs, costs of infections also involve the assessment of intervention and prevention and should be analysed essentially on two levels: macro (the economy) and individual (Różańska, 2009a, p. 80).

Cost analysis can be conducted from various perspectives depending on the needs and the purpose of an analysis. The economic analysis in healthcare introduces mainly two types of costs: direct and indirect. At the macroeconomic level, the society is to incur all the costs associated with infections, including indirect costs resulting from, for instance, a delay in the return of patients to daily activities in a certain profession, and also direct costs associated with the patients' treatment. The indirect costs may consist of:

- higher costs as various types of social benefits,

- lower budget income resulting from the drop in productivity,

- premature deaths,

- opportunity costs of investing limited resources in treatment of cases with complications.

Direct costs are more tangible and easily measured. They cannot be missed regardless of the perspective of the scale. Direct costs (for the previously mentioned nosocomial infection) may consist of infection-related extension of hospitalisation, cost of staying at a hotel for the family and significant others, costs of antibiotics, additional therapeutic and diagnostic procedures, and labour costs of health professionals (Różańska, 2016, pp. 535-537).
Microeconomic level

in relation to the three major groups: patients, payer, care provider (hospitals, for example)
When speaking on infections, the most important issue is measuring the rates of occurrences, while this strictly results from healthcare settings (Khan et al., 2015, p. 512). Due to the heterogeneity of infections, a situation may occur that infection rates show similarities, but in fact, cases differ from each other by the location of the disease. Not only the knowledge on the type of infection and its location is essential: it comes as no surprise that preventive methods, the level of safety precautions and infection management differ depending on whether the health care facility is public or private. The complexity of the issue results in measuring the cases (Fig. 2), leading to the shortage of appropriate, comparable data.

As an example of the complicity in the data collection on issues associated with healthcare infections, the literature and reports repeatedly describe few examples of characteristic (the MRSA: reports on rates of cases can be found in the European Centre for Disease Prevention and Control).

The summary indicators place Poland in the 2nd group ranging between 5-20\% of hospital-associated infections that were classified as resistant. It is also easy to identify the tendency that the rate level increases depending on the environmental conditions, for instance, more cases of resistant infections were reported under conditions conducive to disease development (Cyprus or Spain) than under unfavourable locations (Finland, or Sweden). This increases the importance of the location factor. 
Tab. 1. Methicillin-Resistant Staphylococcus Aureus (MRSA) \% of hospital-acquired infections being resistant in 2012-2015

\begin{tabular}{|c|c|c|}
\hline \multicolumn{2}{|c|}{ MRSA \% OF HOSPITAL-ACQUIRED INFECTIONS BEING RESISTANT } \\
TYPES OF TECHNOLOGY \\
\hline \multicolumn{1}{|c|}{$\begin{array}{c}\text { GROUP 1 } \\
>\mathbf{2 0 \%}\end{array}$} & $\begin{array}{c}\text { GROUP 2 } \\
5-\mathbf{2 0 \%}\end{array}$ & \multicolumn{1}{c|}{$\begin{array}{c}\text { GROUP 3 } \\
<\%\end{array}$} \\
\hline $\begin{array}{l}\text { Croatia, Cyprus, Greece, } \\
\text { Hungary, Italy, Malta, Portugal, } \\
\text { Romania, Slovakia, Spain }\end{array}$ & $\begin{array}{l}\text { Austria, Belgium, Bulgaria, } \\
\text { Czech Republic, France, } \\
\text { Germany, Ireland, Latvia, } \\
\text { Lithuania, Luxembourg, Poland, } \\
\text { Slovenia, Switzerland, UK }\end{array}$ & $\begin{array}{l}\text { Denmark, Estonia, Finland, } \\
\text { Iceland, Netherlands, Norway, } \\
\text { Sweden }\end{array}$ \\
\hline
\end{tabular}

Source: author's elaboration based on (ECDC EARS-net database, 12.12.2016). care systems of European countries.

The mentioned examples indicated that the techniques became widely used due to the multidimensional data on the healthcare system: temporal-sectoral (or sectional)-spatial dimensions, at the same time allowed

\section{RESEARCH METHODS}

Nowadays, quantitative methods are perceived as a necessity in the analysis of the socioeconomics. The need to analyse is particular to the health sector. Quantitative techniques are more frequently incorporated into healthcare analyses to help make difficult decisions, for instance, regarding the financing of one health programme at the expense of others. Any decisions made from the societal point of view should be supported with appropriate tools, measures and techniques.

Few elaborations on the use of the Shift-Share Analysis (SSA) in healthcare are available, while in general, the SSA was used in the description of economic changes. However, the technique, previously reserved by statistics and econometrics, is successfully adopted in healthcare analyses. This tendency can be illustrated by an increasing number of publications and articles in the domestic and foreign literature as well. Hoppes (1997, pp. 35-45) sets an example on incorporating SSA for the analysis of healthcare death rates by disease. In terms of the domestic research, one should indicate numerous applications of the Shift-Share modelling, spatial distribution and concentration analysis, and spatial dependency testing. A similar pattern to the Hoppes's research but realised on a larger scale and from a different perspective (with some spatial modifications) could be seen in the study by Jewczak and Źółtaszek (2011, pp. 87-100), where authors focused on health-related causes of death and conducted the analysis for multiple objects and causes of deaths. RozpędowskaMatraszek (2009, pp. 87-100) incorporated the Shift-Share modelling in healthcare analysis to investigate the employment restructuring changes, whereas Jewczak and Suchecka (2014, pp. 30-38) investigated the changes in the financing of health- conducting multi-faceted analyses, needed for health managers.

\subsection{SPATIAL DisTRIBUTION}

The research on spatial concentration and inequality in economy results presents a combination of two major classical trends: on the one hand, the study on the income inequality and poverty (Sen, 1973) and on the other, the analysis of the industry concentration (Hannah \& Kay, 1977). The theoretical and practical interest in studying the spatial concentration derived additionally from the theory of New Geographical Economy, New Trade and Neoclassical Theories.

For the purposes of spatial distribution analysis as a basic method, location quotients $(L Q)$ are often used. Due to the easiness of calculation and interpretation, $L Q s$ allow identifying regions, areas or places that indicate a higher spatial concentration or even regional specialisation. The $L Q$ indices compare the regional distribution of values of the selected variables with the distribution of the variable at the national level; it can be calculated as follows:

$$
L Q_{r}^{i}=\frac{x_{r i} / x_{r}}{z_{i} / z}
$$

where: $x_{r i}-$ variable values for the $r$-th region and the $i$-th section, $x_{r}$ - variable values for the $\mathrm{r}$-th region, $z_{i}$ - variable values for the $i$-th section, $z-$ the total variables value.

If the $L Q$ measure equals unity $(L Q=1 \pm 0.15)$ than the distribution of the variable located in the region is similar as in the referential object, i.e. the national level. Respectively, on excessed or deficient levels of the spatial concentration of variable values, one can judge when $L Q$ amount to much higher or lower ratios, differing from the uniform distribution. 


\subsection{RATES OF CHANGES - THE ANALYSIS OF GROWTH}

The Shift Share Analysis was firstly proposed in the late 1950s as a method for studying the diversity of the regional growth (Nazar \& Hewings, 2004, pp. 476-490). It allows for the decomposition of changes which have occurred in values of considered variables on components, such as:

- local (connected with the geographic location of the region, its competitiveness or inner diversity),

- ross-sectoral (connected with structural diversity),

- global (connected with the improvement at the national level).

The values of the examined variables are weighted according to their share in the referential variable (reference category) in accordance with a pair of selected time points. The Shift Share model in the basic form can be defined, as follows (Suchecki, 2010, pp. 163-165):

$$
t x_{r \cdot}-t x_{. .}=\sum_{i} u_{r \cdot(i)}\left(t x_{\bullet i}-t x_{. .}\right)+\sum_{i} u_{r \cdot(i)}\left(t x_{r i}-t x_{\bullet i}\right)
$$

where: $x_{r i}$ - variable values for the $r$-th region and the $i$-th section in the initial period, $x_{r i}^{*}$ - variable values for the $r$-th region and the $i$-th section in the final period, $z_{r i}$ - referential variable values for the $r$-th region and the $i$-th section in the initial period, $z_{r i}^{*}$ - referential variable values for the $r$-th region and the i-th section in the final period of analysis, $u_{r \cdot(i)}$ - weights/regional shares defined as:

$$
u_{r \cdot(i)}=\frac{z_{r i}}{\sum_{i} z_{r i}}
$$

$t x_{r i}$ - the regional change rate for the $r$-th region and the $i$-th section, defined as:

$$
t x_{r i}=\frac{x_{r i}^{*}-x_{r i}}{x_{r i}}
$$

$t x_{r .}$ - the average change rate for the $r$-th region, defined as:

$$
t x_{r .}=\sum_{i} u_{r .(i)} \cdot t x_{r i}
$$

$t x_{. i}$ - the average change rate for the $i$-th section, defined as:

$$
t x_{. i}=\sum_{r} \frac{z_{r i}}{\sum_{r} z_{r i}} \cdot t x_{r i}
$$

$t x$.. - the average global change rate, defined as:

$$
t x_{. .}=\sum_{i} \sum_{r} \frac{z_{r i}}{\sum_{i} \sum_{r} z_{r i}} \cdot t x_{r i}
$$

Often, in practical applications, a simplified version of the model is adopted. In this version, the SSA can be defined as follows:

$$
c_{r}=S r+g_{r}
$$

where:

$$
c_{r}=t x_{r}-t x_{. .}
$$

indicates the net effect value,

$$
s_{r}=\sum_{i} u_{r \cdot(i)}\left(t x_{\bullet i}-t x_{. .}\right)
$$

states for the structural component effect and

$$
g_{r}=\sum_{i} u_{r \cdot(i)}\left(t x_{r i}-t x_{\bullet i}\right)
$$

presents the local component effect.

In the initial assumption, the classical SSA approach method uses a fixed weight, and, therefore, does not take into account the possible changes in the reference variable. If analysed points are not too remote in time, the adoption of fixed weights does not generate significant errors. However, if the variables are tested over several years, the assumption of fixed weights appears to be unjustified, and it indicates analysing the consecutive periods in a stringwise manner. Numerous modifications to solve this and other problems of SSA methods have been made that could be summarised schematically using the Fig. 3.

In 1988, Barff and Knight (1998) corrected the classical SSA with a dynamic approach, in which for each pair of consecutive periods of time, to update the weights, the SSA model is determined and the corresponding effects are further summed up as follows:

$$
\sum_{t} c_{r t}=\sum_{t} S_{r t}+\sum_{t} g_{r t}
$$

where: $t$ - indicates a period.

Subsequent modifications were made in 2004 by Nazar and Hewings (2004, pp. 476-490), who proposed introducing spatial weights matrix W (Suchecki, 2010, pp. 105-107, 194-198) into the classical SSA model to consider the spatial interactions (dynamic spatial SSA is also possible). 
Both the spatial distribution (concentration) and the Shift Share Analysis require data summarised in a contingency table. For this reason, the analyses are conducted simultaneously and in some sense results, although $L Q$ s and $S S A$ indicate different phenomena, could be interpreted in a complementary manner.

\section{RESEARCH RESULTS}

The contingency table consisted of data on incidences of infectious diseases and poisonings in years 2005-2015. The Local Data Bank (LDB) of the Central Statistical Office (CSO) in Warsaw was the source of data. To evaluate the spatial units, the NUTS-2 division was adopted (split into voivodships). where the first line represents the level for 2005 and the second one for 2015. The intensity of the phenomena apart from the quotient value was illustrated by the background pattern. The spatial diversification analysis allowed identifying the outstanding levels of concentration for trichinellosis in Lubuskie, shigellosis in Warmińsko-Mazurskie, and AIDS in Dolnośląskie. From the results of the analysis, the overall tendencies outline that the level of concentration decreases with time. Of course, from the viewpoint of the society, the lack of incidences or low values of $L Q$ indicate the absence of infections, which is a positive development.

The desired changes in tendencies also confirmed the results of the SSA (Tab. 3).

As it could be observed, the national (referential) growth rate amounted to $-27.29 \%$ for static and

\begin{tabular}{|c|c|c|c|}
\hline \multicolumn{2}{|c|}{ Classical approach to SSA } \\
\hline Deterministic approach & Stochastic approach \\
\hline Dynamic SSA & Spatial SSA & $\begin{array}{c}\text { Dynamic and } \\
\text { spatial SSA }\end{array}$ & $\begin{array}{c}\text { Variance analysis } \\
\text { (SSANOVA, SSANOVA2) }\end{array}$ \\
\hline
\end{tabular}

Fig. 3. Classification of Shift-Share Analysis methods

Source: authors' elaboration based on (Żółtaszek \& Jewczak, 2011, p. 145).

While comparing the regional/spatial distribution, only the initial and final time periods were used (the 2005 and 2015); however, the SSA presented in the paper was conducted in static and dynamic schemes and the results were further compared to indicate the differences in estimates of the approaches.

It should be emphasised that statistical data presented in the LDB of the CSO, despite merging different classifications of infections, allowed for data aggregation to a contingency table; in the final database, the following list of infections was used: tetanus, whooping cough, measles, viral hepatitis type B, C and A, rubella, AIDS, salmonella, shigellosis, other bacterial food intoxications, acute diarrhoea in children under 2 years, scarlet fever, bacterial meningitis and/or encephalitis, viral meningitis, viral encephalitis, mumps, trichinellosis.

Results presented in Tab. 2 summarise the spatial diversification comparison and its change over time. The columns represent regions with the abbreviations given below. For each infection type and voivodship, LQ values were calculated in the manner of pairs,
$-14.72 \%$ for a dynamic approach. In both cases, estimates confirmed a decrease in the number of incidences of infectious diseases reported on the national level. The regions that recorded a positive change in rates of infections showed a "negative" level of the net effect. The obtained results also demonstrated that the impact of structural changes in some cases (in Podkarpackie, for example) was stronger than local factors; however, the regional changes were mostly affected by the local component. In Dolnośląskie, the increase in the number of infections was the result of changes in the structural distribution due to the positive (decreasing) influence of local activities. It is worth mentioning that the rank of Świętokrzyskie Voivodship, where the highest limitations in the number of infections were estimated as rates indicated (especially for the dynamic SSA), this desirable situation was a consequence of the complexed lowering of several infections.

On the other hand, it cannot be overlooked that some regions noted a rapid increase in the rates of infections, for instance: Lubuskie, Pomorskie and 
Tab. 2. Estimates of the concentration - values of location quotients $L Q$

\begin{tabular}{|c|c|c|c|c|c|c|c|c|c|c|c|c|c|c|c|c|}
\hline \multirow{2}{*}{ INFECTIONS } & \multicolumn{16}{|c|}{ VoIVODSHIPS } \\
\hline & DL & KP & LUL & LUS & LO & MP & $\mathrm{MZ}$ & OP & PK & PD & PM & SL & sw & WM & WP & ZP \\
\hline \multirow{2}{*}{ Tetanus } & 1.50 & & 0.98 & & & 4.18 & 0.58 & 2.65 & 3.56 & & 1.46 & 2.13 & & & & \\
\hline & 1.52 & & & 3.28 & 1.42 & 4.16 & 0.50 & 3.61 & & & 1.74 & & & & & 1.86 \\
\hline \multirow{2}{*}{$\begin{array}{l}\text { Whooling } \\
\text { cough }\end{array}$} & 0.34 & 0.97 & 0.28 & 0.78 & 3.83 & 0.49 & 1.71 & 1.59 & 0.32 & 3.53 & 1.13 & 0.62 & 0.38 & 0.38 & 0.53 & 0.32 \\
\hline & 0.55 & 1.40 & 0.54 & 0.54 & 2.32 & 0.97 & 1.36 & 0.54 & 0.48 & 1.55 & 0.66 & 0.94 & 0.31 & 0.32 & 1.82 & 0.60 \\
\hline \multirow{2}{*}{ Measles } & & & & & 1.29 & 3.48 & 0.59 & & 2.55 & & 1.69 & 3.69 & & & & \\
\hline & 1.52 & 0.33 & & & & 2.30 & 0.99 & 0.93 & 0.56 & 0.70 & 0.25 & 0.35 & & & 1.58 & 5.12 \\
\hline \multirow{2}{*}{$\begin{array}{l}\text { Viral hepatits } \\
\text { type B }\end{array}$} & 2.83 & 0.80 & 0.89 & 2.13 & 1.82 & 0.74 & 0.86 & 1.13 & 0.69 & 0.75 & 1.67 & 0.99 & 0.96 & 0.46 & 0.67 & 0.76 \\
\hline & 1.37 & 1.45 & 0.49 & 0.74 & 1.51 & 0.28 & 0.41 & 0.99 & 0.57 & 1.13 & 1.51 & 1.57 & 0.55 & 1.32 & 1.28 & 1.23 \\
\hline \multirow{2}{*}{$\begin{array}{l}\text { Viral hepatits } \\
\text { type C }\end{array}$} & 2.72 & 0.84 & 1.13 & 3.52 & 1.51 & 0.42 & 0.99 & 0.40 & 0.63 & 0.37 & 2.23 & 0.86 & 1.99 & 0.42 & 0.63 & 0.82 \\
\hline & 1.79 & 1.68 & 1.24 & 1.65 & 1.46 & 0.43 & 0.58 & 0.89 & 0.72 & 0.88 & 0.55 & 1.14 & 1.22 & 1.39 & 1.26 & 1.12 \\
\hline \multirow{2}{*}{$\begin{array}{l}\text { Viral hepatits } \\
\text { type A }\end{array}$} & 0.83 & 0.44 & 2.99 & & 0.92 & 1.67 & 0.85 & 2.94 & & 2.18 & 1.22 & 0.75 & 0.32 & & 0.42 & 2.69 \\
\hline & 0.37 & 0.63 & 1.20 & & 2.78 & 2.45 & 0.97 & 0.88 & 2.18 & 0.68 & 0.25 & 1.20 & & & 0.44 & \\
\hline \multirow{2}{*}{ Rubella } & 2.83 & 1.37 & 0.42 & 1.68 & 0.94 & 0.81 & 1.38 & 0.80 & 1.30 & 0.95 & 0.90 & 1.56 & 0.70 & 0.74 & 0.72 & 0.93 \\
\hline & 1.22 & 1.86 & 0.94 & 1.88 & 0.49 & 0.85 & 0.97 & 1.27 & 1.57 & 0.88 & 0.57 & 0.96 & 0.95 & 1.18 & 1.26 & 1.60 \\
\hline \multirow{2}{*}{ AIDS } & 8.56 & 0.55 & 0.74 & 1.34 & 1.20 & 0.65 & 0.38 & 0.57 & & 0.85 & 1.58 & 0.86 & 0.12 & 1.62 & 0.33 & 0.29 \\
\hline & 3.73 & 0.38 & 0.61 & 0.32 & 1.81 & 0.33 & 0.45 & 1.42 & 0.22 & 2.19 & 1.83 & 0.97 & & 2.52 & 0.76 & 1.65 \\
\hline \multirow{2}{*}{ Salmonella } & 1.22 & 0.95 & 1.38 & 2.73 & 0.92 & 1.69 & 1.12 & 0.74 & 1.85 & 1.38 & 1.63 & 0.63 & 0.54 & 0.85 & 0.54 & 1.48 \\
\hline & 0.94 & 0.82 & 1.54 & 0.62 & 1.35 & 1.15 & 0.96 & 0.95 & 1.92 & 1.17 & 0.78 & 0.73 & 1.13 & 1.40 & 0.93 & 0.70 \\
\hline \multirow{2}{*}{ Shigellosis } & & 0.14 & 1.13 & & & 0.75 & 0.29 & 1.49 & 1.34 & & 1.93 & 0.30 & & 11.85 & & 3.99 \\
\hline & & 1.80 & & & 0.95 & 5.00 & 0.33 & & & & 0.67 & 1.40 & & 1.91 & & \\
\hline \multirow{2}{*}{$\begin{array}{l}\text { Other } \\
\text { bacterial } \\
\text { food } \\
\text { introxications }\end{array}$} & 2.27 & 0.37 & 0.27 & 2.13 & 0.97 & 1.33 & 0.36 & 0.35 & 0.26 & 2.96 & 3.50 & 1.53 & 0.25 & 0.88 & 0.28 & 3.82 \\
\hline & 2.59 & 0.44 & 0.12 & 2.89 & 0.54 & 0.19 & 0.59 & 0.39 & 0.46 & 0.64 & 0.49 & 3.32 & 2.19 & 0.33 & 0.36 & 1.12 \\
\hline \multirow{2}{*}{$\begin{array}{l}\text { Acute } \\
\text { diarrhoea in } \\
\text { children } \\
\text { under } 2 \text { years }\end{array}$} & 1.30 & 0.76 & 0.78 & 0.36 & 0.93 & 0.96 & 0.84 & 0.52 & 1.64 & 1.71 & 1.81 & 0.92 & 1.70 & 1.94 & 0.76 & 0.76 \\
\hline & 0.94 & 0.79 & 1.17 & 1.36 & 0.85 & 1.19 & 0.98 & 1.36 & 1.17 & 1.12 & 1.92 & 0.81 & 0.97 & 1.14 & 1.97 & 0.92 \\
\hline \multirow{2}{*}{ Scarlet fever } & 2.49 & 0.76 & 0.36 & 2.14 & 0.72 & 1.38 & 1.17 & 1.82 & 0.87 & 0.71 & 1.58 & 1.46 & 0.38 & 2.87 & 0.69 & 0.84 \\
\hline & 0.94 & 1.18 & 0.76 & 0.92 & 0.84 & 0.92 & 1.20 & 1.78 & 0.64 & 0.52 & 1.74 & 1.20 & 1.96 & 0.63 & 0.85 & 1.18 \\
\hline \multirow{2}{*}{$\begin{array}{l}\text { Bacterial } \\
\text { meningitis } \\
\text { and/or } \\
\text { encephalitis }\end{array}$} & 0.94 & 0.72 & 0.53 & 3.46 & 0.76 & 1.27 & 1.37 & 1.15 & 1.15 & 1.82 & 1.74 & 1.50 & 0.82 & 1.44 & 0.52 & 1.46 \\
\hline & 1.43 & 1.19 & 1.13 & 1.89 & 1.80 & 0.88 & 0.56 & 1.38 & 1.14 & 0.92 & 0.83 & 1.18 & 1.98 & 1.75 & 0.83 & 1.48 \\
\hline \multirow{2}{*}{$\begin{array}{l}\text { Viral } \\
\text { meningitis }\end{array}$} & 0.83 & 0.90 & 0.44 & 1.13 & 0.29 & 1.41 & 0.77 & 1.14 & 3.13 & 4.85 & 1.32 & 0.47 & 0.45 & 1.39 & 0.54 & 2.67 \\
\hline & 1.27 & 0.91 & 0.46 & 1.58 & 0.74 & 0.75 & 0.44 & 1.88 & 1.72 & 4.47 & 1.15 & 0.44 & 0.83 & 2.75 & 0.79 & 1.63 \\
\hline \multirow{2}{*}{$\begin{array}{l}\text { Viral } \\
\text { encephalitis }\end{array}$} & 0.92 & 0.19 & 0.23 & & 0.25 & 0.15 & 0.80 & 2.26 & 3.27 & 1.42 & 1.41 & 0.39 & 0.29 & 3.57 & 0.62 & 0.75 \\
\hline & 0.93 & 0.56 & 0.82 & 0.14 & 0.75 & 0.55 & 0.57 & 0.95 & 0.98 & 1.66 & 0.48 & 0.50 & 1.65 & 3.38 & 0.43 & 0.82 \\
\hline \multirow{2}{*}{ Mumps } & 0.36 & 1.16 & 1.23 & 0.32 & 1.00 & 0.98 & 0.99 & 1.22 & 0.71 & 0.52 & 0.36 & 1.93 & 1.28 & 0.71 & 1.33 & 0.87 \\
\hline & 0.82 & 1.32 & 1.52 & 1.23 & 0.72 & 0.87 & 0.86 & 1.39 & 0.85 & 1.66 & 0.84 & 1.14 & 1.82 & 0.76 & 0.94 & 1.37 \\
\hline \multirow{2}{*}{ Trichinellosis } & & 1.93 & 0.43 & 1.33 & & & & & & 0.56 & & & & & 6.24 & 0.41 \\
\hline & 0.67 & & & & 17.11 & & & 3.94 & & & & & & & & \\
\hline
\end{tabular}

Source: authors' elaboration based on the statistical database of the Central Statistical Office in Warsaw.

Note: DL - Dolnośląskie, KP - Kujawsko-Pomorskie, LUL - Lubelskie, LUS - Lubuskie, LO - Łódzkie, MP - Małopolskie, MZ - Mazowieckie, OP - Opolskie, PK - Podkarpackie, PD - Podlaskie, PM - Pomorskie, SL - Śląskie, SW - Świętokrzyskie, WM - Warmińsko-Mazurskie, WP - Wielkopolskie, ZP - Zachodniopomorskie. 
Tab. 3. Estimates of the effects for the SSA - the summary of static and dynamic approach with a comparison [\%]

\begin{tabular}{|c|c|c|c|c|c|c|c|c|c|}
\hline \multirow{2}{*}{ VOIVODSHIP } & \multicolumn{3}{|c|}{$\begin{array}{c}\text { SSA EFFECT FOR STATIC } \\
\text { APPROACH }\end{array}$} & \multicolumn{3}{|c|}{$\begin{array}{l}\text { SSA EFFECT FOR DYNAMIC } \\
\text { APPROACH }\end{array}$} & \multicolumn{3}{|c|}{ MODULE DIFFERENCES OF EFFECTS } \\
\hline & Net & $\begin{array}{l}\text { STRUC- } \\
\text { TURAL }\end{array}$ & LOCAL & Net & $\begin{array}{l}\text { STRUC- } \\
\text { TURAL }\end{array}$ & LOCAL & Net & $\begin{array}{l}\text { STRUC- } \\
\text { TURAL }\end{array}$ & LOCAL \\
\hline DL & 16.97 & 42.30 & -25.33 & 15.40 & 56.35 & -40.95 & 0.38 & 14.05 & 15.62 \\
\hline KP & -21.20 & -14.56 & -6.65 & -4.48 & 9.55 & -14.02 & 18.41 & 24.10 & 7.38 \\
\hline LUL & -29.92 & -22.12 & -7.79 & -23.37 & 78.27 & -101.64 & 7.30 & 100.39 & 93.84 \\
\hline LUS & 103.48 & 24.42 & 79.06 & 124.96 & 24.36 & 100.60 & 27.67 & 0.06 & 21.54 \\
\hline LO & -1.58 & 4.64 & -6.23 & 13.21 & -7.35 & 20.55 & 15.53 & 11.99 & 26.78 \\
\hline MP & 36.93 & 2.61 & 34.32 & 100.40 & -3.78 & 104.18 & 63.58 & 6.39 & 69.86 \\
\hline $\mathrm{MZ}$ & 20.00 & 0.52 & 19.48 & 26.76 & 11.06 & 15.70 & 7.12 & 10.54 & 3.78 \\
\hline OP & -6.13 & -15.12 & 8.99 & 9.74 & -25.17 & 34.90 & 17.01 & 10.05 & 25.92 \\
\hline PK & -0.20 & 19.54 & -19.75 & 4.93 & 21.29 & -16.37 & 6.85 & 1.75 & 3.38 \\
\hline PD & 12.65 & 31.85 & -19.21 & 16.81 & -11.87 & 28.69 & 6.95 & 43.73 & 47.89 \\
\hline PM & 60.22 & 49.49 & 10.73 & 61.83 & 40.80 & 21.03 & 3.08 & 8.69 & 10.31 \\
\hline SL & -3.24 & -6.33 & 3.09 & 4.75 & 8.47 & -3.72 & 7.99 & 14.80 & 6.81 \\
\hline SW & -39.96 & -16.47 & -23.50 & -71.88 & -69.76 & -2.11 & 31.54 & 53.30 & 21.38 \\
\hline WM & -19.69 & 44.77 & -64.45 & -34.77 & 13.24 & -48.02 & 13.18 & 31.52 & 16.44 \\
\hline WP & -21.88 & -21.84 & -0.03 & 13.17 & -53.71 & 66.88 & 35.72 & 31.87 & 66.92 \\
\hline ZP & 21.53 & -9.74 & 31.28 & 33.66 & 10.55 & 23.11 & 12.86 & 20.29 & 8.17 \\
\hline Total effect & 127.97 & 113.96 & 14.01 & 291.12 & 102.30 & 188.82 & $\begin{array}{l}\text { Absolute } n \\
\text { difference }\end{array}$ & onal growt & ate \\
\hline National growth rate & & & -27.29 & & & -14.72 & & & 12.57 \\
\hline
\end{tabular}

Source: authors' elaboration based on (the statistical database of the Central Statistical Office in Warsaw).

Note: abbreviations as in Tab. 2.

Małopolskie. The unfavourable situations resulted mainly from the local conditions and regional factors. The estimates should be of particular interest to local authorities.

The differences in estimates resulted from SSA approaches applied in the research and should be labelled as significant, indicating the preference for a complexed, and at the same time, more accurate dynamic analysis.

\section{DISCUSSION OF THE RESULTS}

It is complicated to receive reliable data on healthcare infections to calculate their direct impact on the economy and society, with direct and/or indirect cost for the system. As already mentioned, the research indicated that various Authors focus on the issue of infections differently; at the same time, the data accessibility differs depending on the aim of analysis. These implications result from the fact that each infection incidence has its conditioning, for example, location, environmental determinants, and different origin. The database of the European Centre for Disease Prevention and Control (ECDC) indicates that it is possible to reduce the number of infection cases. This is also confirmed by this paper. It is undeniable that there was a significant decline in the number of infection cases. The differences in estimates, however, indicated the use of more complex methods, such as stochastic $S S A$ approaches or spatial SSA analyses.

Hoppes (1997) indicated that the use of the SSA results was important due to possibilities to investigate the general trends (the national growth rates), the influence of a disease (structural growth rates), and the local conditions (the competitive advantage/ disadvantage). Clearly, the specific SSA results may turn out useful in the design of preventive health programmes, allowing the forecast of their scope, range and location.

Positively, from the perspective of the society, it should be evaluated that the national growth rate is 
negative, which indicated the decrease in the number of incidence of infections. However, while interpreting the values of section net rates (for a specific disease), one can conclude that in some instances, the number of cases increased rapidly, for example, measles, whooping cough, scarlet fever or acute diarrhoea in children under two years of age. This necessitates considering the results of the dynamic approach as more reliable as the same conclusion was derived from the research on health-related causes of deaths (Jewczak \& Żółtaszek, 2011).

The analysis was also performed for rates of incidence of infections in conversion to the number of regional inhabitants to confirm the correctness of previously adopted schemes. Although there were no significant differences, one should bear in mind that the state of being infected might not be recorded in a location of permanent residence that is the evidence for further spatial/territorial modifications of the Shift-Share Analysis.

\section{CONCLUSIONS}

Summarising the analyses and research, it should be emphasised that the spatial concentration of infections weakens in time, which could be indicative of positive changes for the economy (the budget), healthcare (the system), and society (the patients). This conclusion might be beneficial from the perspective of the healthcare sector due to easier predictive scenarios for future infections and possible centres of the increase in incidence as well as the economic and societal costs. Moreover, results showed that for some types of infections, a location played an important role. This assumption was indirectly confirmed by the documentation of the European Centre for Disease Prevention and Control.

Although the SSA does not indicate the factors influencing the level of infection cases or their spatial distribution, its results are useful to identify and categorise the reasons for observed changes, helping to make justified decisions, while allocating the resources in the healthcare system.

The Shift Share Analysis indicated regions that experienced relatively higher rates of changes in the number of reported cases: the growth rate amounted to $-27.29 \%$ for static and $-14.72 \%$ for the dynamic approach and in both cases, the estimates confirmed a decrease in time, which implies a higher safety of local societies. Beside the net growth (or the net effect), the SSA revealed the background of those fluctuations, whether it was an influence of local conditions or structural (typological) changes. Especially, those results should be wisely adapted, for instance, in preventive strategies of local or national governments.

Finally, the results also confirmed the disadvantage of static approaches in favour of more developed, accurate approaches. The estimates showed that applying the constant distributional rates for the analysis of the phenomena of high volatility results in revalued levels of net, structural and local effects.

\section{LITERATURE}

Barff, R. A., \& Knight, P. L. (1998). Dynamic Shift-Share Analysis. Growth and Change, 19(2), 1-10.

Centers for Disease Control and Prevention. (2016). Diseases and Organisms in Healthcare Settings. Retrieved from https://www.cdc.gov/hai/organisms/organisms.html

Cianciara, J. (2010). Skala zagrożeń zakażeniami szpitalnymi. Metody prewencji [The scale of the risks hospital infections. Prevention methods]. Zakażenia szpitalne. Retrieved from http://www.rynekzdrowia. $\mathrm{pl} /$ Serwis-Zakazenia-Szpitalne/Skala-zagrozen$\mathrm{z}$ a k a z e n i a m i - s z p i t a ln y m i - M e t od y prewencji,102680,1015.html

Czerw, A., Religioni, U., \& Olejniczak, D. (2012). Metody pomiaru oraz oceny jakości świadczonych usług w podmiotach leczniczych [Methods of service quality measurement and evaluation in medical entities]. Przegląd Epidemiologiczny, 93(2), 269-273.

Denys, A. (Ed.). (2013). Zakażenia szpitalne $w$ wybranych oddziałach: Część II [Nosocomial infections in selected hospital departments: Part II]. Warszawa, Poland: Wolters Kluwer.

Dziewa, A., \& Ksykiewicz-Dorota, M. (2012). Metody monitorowania i rejestracji zakażeń szpitalnych [Methods of monitoring and recording of nosocomial infections]. Hygeia Public Health, 47(1), 56-63.

Hannah, L., \& Kay, J. A. (1977). Concentration in modern industry. Theory, measurement and the UK experience. London, England: Macmillan.

HEXAL podręczny leksykon medycyny [HEXAL handy lexicon of medicine]. (1996). Wrocław, Poland: Urban \& Partner.

Hoppes, R. B. (1997). Shift-share analysis for regional health care policy. The Journal of Regional Analysis \& Policy, 27(1), 35-45.

Jewczak, M., \& Żółtaszek, A. (2011). Spatial Shift-Share Analysis as a health policy tool. Folia Oeconomica, 252, 87-100. 
Jewczak, M., \& Suchecka, J. (2014). Finansowanie opieki zdrowotnej w wybranych krajach Europy [Financing of healthcare in selected European countries]. In A. Depta (Ed.), Zarządzanie zdrowiem a problemy społeczeństwa obywatelskiego [Health management and society problems], (pp. 30-38). Łódź, Poland: Wydawnictwo Politechniki Łódzkiej.

Khan, H. A., Ahmad, A., \& Mehoob, R. (2015). Nosocomial infections and their control strategies. Asian Pacific Journal of Tropical Biomedicine, 5(7), 509-514.

Khan, H. A., Baig, F. K., \& Mehboob, R. (2017). Nosocomial infections: Epidemiology, prevention, control and surveillance. Asian Pacific Journal of Tropical Biomedicine, 7(5), 478-482. doi: 10.1016/j. apjtb.2017.01.019

Mała Encyklopedia PWN [Small Encyclopedia of PWN]. (1995). Warszawa, Poland: PWN.

McKibben, L., Horan, T., Tokars, J. I., Fowler, G., Cardo, D. M., Pearson, M. L., \& Brennan, P. J. (2005). Guidance on Public Reporting of Healthcare-Associated Infections: Recommendations of the Healthcare Infection Control Practices Advisory Committee. American Journal of Infection Control, 33(4), 217-226. doi: 10.1016/j.ajic.2005.04.001

Nazara, S., \& Hewings, G. J. D. (2004). Spatial structure and Taxonomy of Decomposition in shift-share analysis. Growth and Change, 35(4), 476-490.

Opolski, K., Dykowska, G., \& Możdżonek, M. (2003). Zarządzanie przez jakość w usługach zdrowotnych. Teoria i praktyka [Quality management in health services. Theory and practice]. Warszawa, Poland: CeDeWu.

Profilaktyka $i$ zwalczanie zakażeń szpitalnych [Prevention and combating of nosocomial infections]. (2016). Conference materials.

Rozpędowska-Matraszek, D. (2012). Panelowy model SSANOVA wykorzystany do oceny wpływu efektów zróżnicowania sektorowego i regionalnego na prowadzoną restrukturyzację zatrudnienia w opiece zdrowotnej w Polsce w latach 1999-2009 [The SSANOVA panel model applied to assess the impact of sector and regional diversification effects on employment restructuring in health care in Poland from 1999 to 2009]. Kolegium Analiz Ekonomicznych Szkoły Głównej Handlowej, 27, 87-100.

Różańska, A. (2009a). Ekonomika zakażeń szpitalnych [Economics of nosocomial infections]. In P. Heczko, J. Wójkowska-Mach (Eds.), Zakażenia szpitalne. Podręcznik dla zespołów kontroli zakażeń [Nosocomial infections. Handbook for infection control groups], (p. 80). Warszawa, Poland: Wydawnictwo Lekarskie PZWL.

Różańska, A. (2009b). Ekonomika zakażeń szpitalnych [Economics of nosocomial infections]. In P. Heczko, J. Wójkowska-Mach (Eds.), Zakażenia szpitalne. Podręcznik dla zespołów kontroli zakażeń [Nosocomial infections. Handbook for infection control groups], (p. 81). Warszawa, Poland: Wydawnictwo Lekarskie PZWL.
Różańska, A. (2016). Analiza ekonomiczna w kontroli zakażeń [An economic analysis in infection control]. In M. Bulanda, J. Wójkowska-Mach (Eds), Zakażenia szpitalne $w$ jednostkach opieki zdrowotnej [Nosocomial infections in health care units], (pp. 535-537). Warszawa, Poland: Wydawnictwo Lekarskie PZWL.

Różańska, A., Wójkowska-Mach, J., Bulanda, M., \& Heczko, P. (2014). Organizacja i zakres kontroli zakażeń w polskich szpitalach. Wyniki programu PROHIBIT [Organisation and infection control in polish hospitals. The results of PROHIBIT programme]. Przeglad Epidemiologiczny, 68, 117-120.

Sen, A. (1973). On Economic Inequality. Oxford, England: Oxford Clarendon Press.

Suchecki, B. (Ed.). (2010). Ekonometria Przestrzenna [Spatial Econometrics]. Warszawa, Poland: C. H. Beck.

Ustawa $z$ dnia 5 grudnia 2008 r. o zapobieganiu oraz zwalczaniu zakażeń i chorób zakaźnych u ludzi [Act from the 5th of December 2008 preventing and fighting infections and infectious diseases affecting humans] (Dz. U. 2008, nr 234, poz. 1570) 2008 (PL).

Vincent, J. L., Rello, J., Marshall, J., Silva, E., Anzueto, A., Martin, C. D., Moreno, R., Lipman, J., Gomersall, C., Sakr, Y., \& Reinhart, K. (2009). International Study of the Prevalence and Outcomes of Infection in Intensive Care Units. Journal of the American Medical Association, 302(21), 2323-2329. doi: 10.1001/ jama.2009.1754

Wójkowska-Mach, J. (2009). Regulacje prawne w nadzorze nad zakażeniami szpitalnymi [Law regulations in the supervision of nosocomial infections]. In P. Heczko, J. Wójkowska-Mach (Eds.), Zakażenia szpitalne. Podręcznik dla zespołów kontroli zakażeń [Nosocomial infections. Handbook for infection control groups], (p. 86).Warszawa, Poland: Wydawnictwo Lekarskie PZWL.

Żółtaszek, A., \& Jewczak, M. (2011). Spatial and dynamic analysis of health care expenditures in OECD countries. Folia Oeconomica, 252, 143-158. 